\title{
Studies on the Effect of Pruning on Cucumber cv. Malini Grown Under Protected Conditions
}

\author{
D. Shivaraj ${ }^{1}$ *, D. Lakshminarayana ${ }^{2}$, P. Prasanth ${ }^{3}$ and T. Ramesh ${ }^{3}$ \\ ${ }^{1}$ Department of Vegetable Science, ${ }^{2}$ Department of Floriculture and Landscaping, \\ College of Horticulture, Mojerla, SKLTS Horticultural University, Rajendranagar, \\ Hyderabad - 500032, India \\ ${ }^{3}$ Department of Crop Physiology, College of Agriculture, PJTS Agricultural University, \\ Rajendranagar, Hyderabad - 500032 \\ *Corresponding author
}

\section{A B S T R A C T}

\begin{tabular}{|l|}
\hline Ke y w o r d s \\
Pruning on \\
Cucumber cv. \\
Malini, \\
Cucumis sativus
\end{tabular}

Keywords

Pruning on

Malini,

Cucumis sativus
An investigation was conducted to study the effect of Pruning and Training systems on Cucumber cv. Malini grown under protected conditions. The whole experiment was arranged over 12 treatments consisting of 4 levels of Pruning, $P_{1}$ (Removal of flower buds up to $45 \mathrm{~cm}$ ), $P_{2}$ (Removal of flower buds up to $60 \mathrm{~cm}$ ), $P_{3}$ (Removal of flower buds up to $75 \mathrm{~cm}$ ) and $\mathrm{P}_{4}$ (No Pruning). The characters like vine length, leaf area, days to first flowering, days to first harvest, number of fruits per vine, fruit length, fruit diameter etc. were significantly influenced by pruning systems. The significant differences for vine length and leaf area were observed among various treatments and $\mathrm{P}_{2}$ recorded high value for these characters which was at par with $\mathrm{P}_{3}$ and $\mathrm{P}_{1} . \mathrm{P}_{2}$ registered significantly highest number of fruits per plant (23.77), higher yield per vine and per hectare $(6.40 \mathrm{~kg}$ and $141.68 \mathrm{t} / \mathrm{ha}$ ) having statistically similar results with that of $\mathrm{P}_{3}$.

\section{Introduction}

Cucumber (Cucumis sativus L.) is one of the most important and popular vegetable crops grown extensively throughout the tropical and subtropical region of the world. It belongs to the family cucurbitaceae and is native to Southern Asia (Adams et al., 1992). Cucumber is a truly versatile vegetable because of wide range of uses from salads to pickles and digestive aids to beauty products (More, 2015). It is one of the most preferred vegetables grown under protected conditions in the world. Its demand is throughout the year because of its popular use. Cucumber, being a high value low volume crop, its exploitation on commercial scale in naturally ventilated polyhouse can improve productivity and generate good income to the growers. These technologies are highly suitable for the states like Telangana where government is coming with certain schemes for increasing the socioeconomic status of small farmers through high profitability. 
Greenhouse growers often encounter various problems regarding agronomical aspects of the crop. Being a profusely and fast growing plant cucumber plant needs manipulation in its architecture through pruning and training for getting maximum yields of good quality. Pruning of leaves, side branches and flower buds contribute to the ultimate yield in many ways. A dense canopy of leaves shades the fruits causing them to pale. These excess leaves are pruned and sufficient number of leaves is maintained on the plant. Excess pruning may sometimes causes the plants cease flowering. Therefore it is important to maintain sufficient foliage on the plant for adequate rates of photosynthesis (Premalatha et al., 2006). So the investigation was aimed to study the effects of pruning on cucumber grown under protected conditions

\section{Materials and Methods}

A Cucumber variety Malini (Smenes Ltd., India) popular among the cucumber growers in Telangana was taken for the investigation during November, 2016. The experiment was conducted under shade net of $357 \mathrm{~m}^{2}$ at Vegetable Research Block, College of Horticulture - Mojerla, SKLTS Horticultural University, Hyderabad (Telangana) situated at 780 29' East longitude and 170 19' North latitude with an altitude of $542.3 \mathrm{~m}$ above the mean sea level. The location is characterized by semi arid climate.

The whole experiment was arranged over 12 treatments consisting of 4 levels of pruning $\mathrm{P}_{1}$ (Removal of flower buds up to $45 \mathrm{~cm}$ ), $\mathrm{P}_{2}$ (Removal of flower buds up to $60 \mathrm{~cm}$ ), $\mathrm{P}_{3}$ (Removal of flower buds up to $75 \mathrm{~cm}$ ) and $\mathrm{P}_{4}$ (No Pruning). Seeds were sown in triangular method and the description of pruning treatments is as follows. In the pruning treatments $\mathrm{P}_{1}, \mathrm{P}_{2}, \mathrm{P}_{3}$ all the flower buds, lateral branches are pruned up to heights of $45 \mathrm{~cm}, 60 \mathrm{~cm}$ and $75 \mathrm{~cm}$ respectively. In the pruning treatment $\mathrm{P}_{4}$ the plants are left unpruned. The experiment was laid out in a Randomized Complete Block Design (Factorial concept) with three replicates on raised beds having dimensions of $100 \times 40 \times$ $50 \mathrm{~cm}$ (width, height \& distance between two beds) and plot size of $21 \mathrm{~m}$. The data on various parameters viz., vine length, leaf area, days taken to first flowering, days taken to $50 \%$ flowering, days taken to first harvest, number of fruits per vine, fruit length, fruit diameter, fruit weight, fruit yield per vine, fruit yield per plot, fruit yield per hectare, marketable yield, and deformed fruits were recorded on five randomly tagged plants and the mean values were subjected to statistical analysis as per Panse and Sukhatme (1985).

\section{Results and Discussion}

The data pertaining to various yield and yield contributing traits used for evaluation of the treatments were statistically analyzed to test their significance and results of these data have been given in tables 1 and 2 .

\section{Vegetative and fruit parameters}

The plant height and leaf area at all the intervals of growth period of crop were significantly higher in treatment $\mathrm{P}_{2}$. The highest vine length was reported in $\mathrm{P}_{2}$ treatment (291.80) and is on par with $\mathrm{P}_{3}$ and $\mathrm{P}_{1}$ at 90 DAS. Similarly the highest leaf area is also reported in $\mathrm{P}_{2}$ treatment (636.04) and is on par with treatment $\mathrm{P}_{1}$. The highest vine length may be due to the diversion of nutrients to main shoot, resulted in exposure of pruned plant to light conditions, enhanced higher photosynthetic activities. These results were in accordance with that of Suthar et al. (2007). The maximum leaf area might be due to better interception of sunlight into canopy structure. Similar results were reported by Hao et al. (2010). Among different treatments of pruning, $\mathrm{P}_{2}$ took significantly lowest 
number of days to first flowering (30.90) and first harvest (46.66) which was at par with treatment $\mathrm{P}_{1}$ for days to first harvest only. This may be due to the highest vine length and leaf area which supplemented assimilates required and promoted early flowering and early harvest is due to the early flowering of that treatment. The present findings are comparable with that of Suthar et al. (2007) and Hong (2000).

The significant variation for number of fruits per vine fruit length and diameter were recorded by $\mathrm{P}_{2}$ treatment which was on par with treatment $\mathrm{P}_{3}$ for number of fruits per vine only. But for the parameters fruit length and fruit diameter $\mathrm{P}_{2}$ is at par with treatments $\mathrm{P}_{1}$ and $\mathrm{P}_{3}$. This might be due to the maximum leaf area of this treatment which lead to enhanced photosynthetic activities and their accumulation.

The parameter fruit weight also got affected by the effect of pruning treatments significantly. The highest fruit weight was recorded in $\mathrm{P}_{1}(274.02 \mathrm{~g})$ and it is at par with $\mathrm{P}_{2}$ and $\mathrm{P}_{3}$. This might be due to less fruit number, average fruit length, and diameter. These findings are in line with the reports of Vikram kumar et al. (2017).

\section{Yield parameters}

Various levels of pruning imparted significant influence on total yield per vine $(\mathrm{kg})$. Maximum yield was recorded in $\mathrm{P}_{2}(6.40 \mathrm{~kg})$ and it was on par with $\mathrm{P}_{3}$. The results related to parameters fruit yield per plot, yield per hectare and marketable yield were significant. Maximum yield for those parameters were reported in $\mathrm{P}_{2}(70.14 \mathrm{~kg}, 141.68 \mathrm{t} / \mathrm{ha}$ and $137.15 \mathrm{t} /$ ha respectively). And they were on par with $\mathrm{P}_{3}$ for fruit yield per plot and per hectare and not for marketable yield. Pruning also shown significant effect on parameter deformed fruits which are expressed in percentage. Lowest percentage of deformed fruits is reported in $\mathrm{P}_{2}(3.21 \%)$ and it was at par with $\mathrm{P}_{3}$. These results are due to the longest vine length, maximum leaf area, more number of fruits per vine, higher fruit length and diameter of the treatment as compared to others. These results are in conformity with the findings of Suthar and Ram (2006) and Bhatia et al. (2012). The highest marketable yield is due to the pruning methods followed which allowed the fruits to expose to light conditions and resulted in production of healthy fruits. The results were inconsistent with the reports of Hao et al. (2010).

Table.1 Effect of pruning on vegetative traits of cucumber under protected conditions

\begin{tabular}{|c|c|c|c|c|c|c|c|c|}
\hline Treatment & $\begin{array}{c}\text { Vine } \\
\text { length } \\
\text { at } 30 \\
\text { DAS } \\
\text { (cm) }\end{array}$ & $\begin{array}{c}\text { Vine } \\
\text { length } \\
\text { at } 60 \\
\text { DAS } \\
(\mathrm{cm})\end{array}$ & $\begin{array}{c}\text { Vine } \\
\text { length } \\
\text { at } 90 \\
\text { DAS } \\
\text { (cm) }\end{array}$ & $\begin{array}{c}\text { Leaf } \\
\text { area at } \\
\text { 30 DAS } \\
\left(\mathrm{cm}^{2}\right)\end{array}$ & $\begin{array}{c}\text { Leaf } \\
\text { area at } \\
60 \text { DAS } \\
\left(\mathrm{cm}^{2}\right)\end{array}$ & $\begin{array}{c}\text { Leaf } \\
\text { area at } \\
90 \text { DAS } \\
\left(\mathrm{cm}^{2}\right)\end{array}$ & $\begin{array}{c}\text { Days } \\
\text { taken to } \\
\text { first } \\
\text { flowering }\end{array}$ & $\begin{array}{c}\text { Days } \\
\text { taken to } \\
50 \% \\
\text { flowering }\end{array}$ \\
\hline $\mathbf{P}_{1}$ & 93.08 & 202.30 & 289.00 & 347.40 & 485.50 & 625.96 & 31.70 & 36.60 \\
\hline $\mathbf{P}_{2}$ & 100.17 & 210.05 & 291.80 & 348.50 & 500.03 & 636.04 & 30.90 & 36.20 \\
\hline $\mathbf{P}_{3}$ & 101.20 & 204.09 & 290.87 & 345.90 & 492.60 & 634.32 & 31.80 & 36.40 \\
\hline $\mathbf{P}_{4}$ & 88.67 & 197.45 & 281.34 & 340.50 & 479.90 & 601.84 & 32.30 & 36.70 \\
\hline SEm \pm & 1.37 & 0.56 & 1.90 & 1.92 & 2.63 & 0.63 & 0.15 & 0.14 \\
\hline CD at $5 \%$ & S & S & S & S & S & S & S & NS \\
\hline
\end{tabular}

$\mathrm{P}_{1}=$ Removal of flowers up to $45 \mathrm{~cm}, \mathrm{P}_{2}=$ Removal of flowers up to $60 \mathrm{~cm}$, $\mathrm{P}_{3}=$ Removal of flowers up to $75 \mathrm{~cm}$ and $\mathrm{P}_{4}=$ No pruning 
Table.2 Effect of pruning on fruit and yield attributes of cucumber under protected conditions

\begin{tabular}{|c|c|c|c|c|c|c|c|c|c|c|}
\hline Treatment & $\begin{array}{c}\text { Days } \\
\text { taken } \\
\text { to first } \\
\text { harvest }\end{array}$ & $\begin{array}{l}\text { Number } \\
\text { of fruits } \\
\text { per vine }\end{array}$ & $\begin{array}{c}\text { Fruit } \\
\text { length } \\
(\mathrm{cm})\end{array}$ & $\begin{array}{c}\text { Fruit } \\
\text { diameter } \\
\text { (cm) }\end{array}$ & $\begin{array}{c}\text { Fruit } \\
\text { weight } \\
\text { (g) }\end{array}$ & $\begin{array}{l}\text { Fruit } \\
\text { yield } \\
\text { per } \\
\text { vine } \\
(\mathrm{Kg})\end{array}$ & $\begin{array}{c}\text { Fruit } \\
\text { yield } \\
\text { per } \\
\text { plot } \\
(\mathrm{Kg})\end{array}$ & $\begin{array}{c}\text { Fruit } \\
\text { yield } \\
\text { per } \\
\text { hectare } \\
\text { (t/ha) }\end{array}$ & $\begin{array}{l}\text { Marketable } \\
\text { yield (t/ha) }\end{array}$ & $\begin{array}{l}\text { Deformed } \\
\text { fruits }(\%)\end{array}$ \\
\hline $\mathbf{P}_{1}$ & 46.98 & 20.11 & 20.54 & 5.51 & 274.02 & 5.49 & 59.90 & 121.02 & 119.73 & 4.44 \\
\hline $\mathbf{P}_{2}$ & 46.66 & 23.77 & 20.85 & 5.61 & 272.54 & 6.40 & 70.14 & 141.68 & 137.15 & 3.21 \\
\hline $\mathbf{P}_{3}$ & 47.42 & 22.22 & 20.62 & 5.58 & 262.09 & 5.80 & 63.50 & 128.26 & 123.36 & 3.96 \\
\hline $\mathbf{P}_{4}$ & 48.83 & 21.22 & 19.03 & 4.86 & 232.74 & 4.88 & 53.90 & 108.88 & 101.93 & 6.50 \\
\hline SEm \pm & 0.17 & 0.72 & 0.31 & 0.10 & 10.72 & 0.20 & 2.26 & 4.56 & 4.22 & 0.25 \\
\hline CD at $5 \%$ & $\mathrm{~S}$ & $\mathrm{~S}$ & $\mathrm{~S}$ & $\mathrm{~S}$ & $\mathrm{~S}$ & $\mathrm{~S}$ & $\mathrm{~S}$ & $\mathrm{~S}$ & $\mathrm{~S}$ & $\mathrm{~S}$ \\
\hline
\end{tabular}

$\mathrm{P}_{1}=$ Removal of flowers up to $45 \mathrm{~cm}, \mathrm{P}_{2}=$ Removal of flowers up to $60 \mathrm{~cm}$,

$\mathrm{P}_{3}=$ Removal of flowers up to $75 \mathrm{~cm}$ and $\mathrm{P}_{4}=$ No pruning.

In conclusion most of the traits under investigation were influenced by effect of pruning methods. The treatment $\mathrm{P}_{2}$ resulted in maximum gain in yield under protected conditions, which was statistically comparable with $\mathrm{P}_{3}$. The excellent performance of cucumber is a result of congenial microclimate inside the shade net, high yield potential of cucumber supplemented with recommended fertigation dose in properly pruned plants. Therefore, it can be concluded that cultivation of cucumber under shade net is highly profitable through pruning of plants up to $60 \mathrm{~cm}$.

\section{References}

Adams, P., Graves, C.J. and Winsor, G.W. 1992. Some responses of cucumbers, grown in beds of peat to $\mathrm{N}, \mathrm{K}$ and $\mathrm{Mg}$. Hort Science 67: 877-84.

Ali, M.R., Halim, G.M.A. and Mehraj, H. 2016. Stages of vine pruning for vine production of bottle gourd varieties and lines in summer season. Journal of Bioscience and Agriculture research. 09: 792.795.

Al-Obeid, S. 2007. Effect of growth techniques (pruning method) on the production of cucumber grown in greenhouses. Arab University Journal of agriculture science. 15(1): 19-27.

Arora, S.K., Pandita, M.L. and Sidhu, A.S. 1982. Effect of Pruning on vegetative growth, flowering and Yield of round melon (Citrullus vulgaris Var. Fistulosus) Var. Hissar Selection. Indian Journal of Horticulture. 39: 224-229.

Bhatia, A.K., Batra, V.K. and Singh, V.P. 2012. Performance of gynoecious hybrids of cucumber under plastic greenhouse. High value vegetables in Southeast Asia: Production, Supply and Demand (SEAVEG) Report.

Duong, H.X. 1999. Effect of pruning on yield and quality of cucumber. AVRDC Training Report . 51.

Ekwu, L.G., Nwokwu, G.N. and Utobo, E.B. 2012. Effect of mulching materials and pruning on growth and yield of cucumber (Cucumis sativus L.). International Journal of Agriculture and Rural Development. 15(2): 1014-1021.

Hao, X., Wen, G., Papadopoulos, A.P. and Khosla, S. 2010. A twin-head "V" High -wire greenhouse Cucumber production 
system for reducing crop start-up costs. Hort Technology. 20(6): 963-970.

Hong, Q. 2000. Effect of pruning and spacing on yield and quality of cucumber. AVRDC Training Report, China. 7

Hoza, G. 2013. Research regarding the influence of various pruning systems at cornichon Cucumber cultivated in solarium. Journal of horticulture, Forestry and Biotechnology. 17(1): 219222.

More, T.A. 2015. Cucurbitaceous Vegetables (Cucumber). Textbook of Vegetables, Tuber and Spice crops. 254-261.

Okafor, C.G. 2007. Effect of staking and pruning on the vegetative growth and yield of Cucumber. Unpublished undergraduate project. Ebonyi State University, Abakaliki. 95.

Panse, V.G and Sukhatme, P.V. 1985. Statistical methods for agricultural workers. Indian Council of Agricultural Research, New Delhi, India.

Premalatha, M.G.S., Wahundeniya, K.B., Weerakkody, W.A.P. and Wicramathunga, C.K. 2006. Plant training and spatial arrangement for yield improvements in greenhouse Cucumber (Cucumis sativus L.) varieties. Tropical Agricultural Research. 18: 346-357.

Sibgolab Khoshkam. 2016. The effect of pruning and planting density on yield of greenhouses cucumber in jiroft. International Journal of Scientific Engineering and Applied Science. 2: 212-227.

Sowley. E.N.K. and Damba, Y. 2013. Influence of staking and pruning on growth and yield of Tomato in the Guinea Savannah Zone of Ghana. International Journal of Scientific \& Technology Research. 2: $103-108$.

Suthar and Ram, M. 2006. Effect of pruning and ethrel application on vegetative growth and fruit yield of Cucumber under greenhouse condition. Haryana Journal of Horticultural Sciences. 35: 92-95.

Suthar, M.R., Arora, S.K., Bhatia, A.K., Singh, V.P. and Malik, T.P. 2007. Effect of pruning and etheral application on flowering behavior of Cucumber (Cucumis sativus L) under polyhouse conditions. Haryana Journal of Horticultural Sciences. 36: 135-138.

Vikram, K.K., Ameta, K.D., Suresh kumar, T., Akshay,C., Suman, G. and Satveer yadav. 2017. Effect of spacing and training on growth and yield of polyhouse grown Cucumber (Cucumis sativus L.). International Journal of Current Microbiology and Applied Sciences. 6(8): 299 - 304.

\section{How to cite this article:}

Shivaraj, D., D. Lakshminarayana, P. Prasanth and Ramesh, T. 2018. Studies on the Effect of Pruning on Cucumber cv. Malini Grown Under Protected Conditions. Int.J.Curr.Microbiol.App.Sci. 7(03): 2019-2023. doi: https://doi.org/10.20546/ijcmas.2018.703.237 